\section{DETERMINING THE EFFECTS OF RH-WMA ON THE ENGINEERING PROPERTIES OF BITUMEN}

Khansaa Mahmoud Mohammeda, Ibrahim Khalid Abdallaa, Ameen Hadi Mohammedb, Faridah Hanim Khairuddina, Ahmad Nazrul Hakimi Ibrahima, Sri Atmaja P. Rosyidic, Mohd Ezree Abdullahd, Nur Izzi Md. Yusoffa*

aDepartment of Civil and Structural Engineering, Universiti Kebangsaan Malaysia, Selangor, Malaysia

bDepartment of Chemistry, College of Science for Women, University of Baghdad, Baghdad, Iraq

cDepartment of Civil Engineering, Universitas Muhammadiyah Yogyakarta, Yogyakarta, Indonesia

dFaculty of Civil and Environmental Engineering, Universiti Tun Hussein Onn Malaysia, Malaysia
Article history

Received

3 February 2018

Received in revised form

14 December 2018

Accepted

1 January 2019

Published online

18 February 2019

*Corresponding author izzi@ukm.edu.my

\section{Graphical abstract}

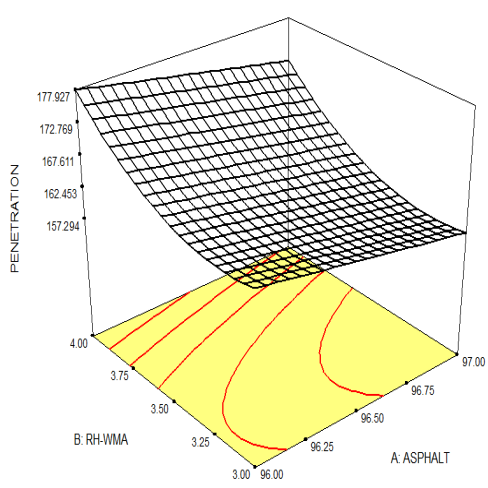

\begin{abstract}
This study aims to investigate the engineering properties (i.e., physical, chemical, and adhesion properties) of bitumen incorporated with $\mathrm{RH}-$ Warm Mix Asphalt (RHWMA) additive. Base bitumen with a penetration grade of $80 / 100$ was added with 3.0, 3.5, and 4.0\% RH-WMA (by total weight of bitumen). The Response Surface Method (RSM) was used to determine the optimum values of the base bitumen and RH-WMA additive which meet the bitumen specification with penetration and softening point chosen as responses in the design layout. Three solutions of 3.04 , 3.55 and $3.91 \%$ RH-WMA additive that were obtained from the RSM analysis were selected as the optimal values. Results of the physical tests show that adding RHWMA increases the penetration and ductility values whilst simultaneously reducing the value for the softening point. Analysis of viscosity at various temperatures shows that RH-WMA additive lowers viscosity when the temperature was raised from 100 to $165^{\circ} \mathrm{C}$. The lower viscosity of the modified binders improves their workability. The result of the Fourier Transform Infrared (FTIR) test shows that there is no complex chemical reaction between the base bitumen and the RH-WMA. The surface free energy (SFE) test conducted on the base bitumen and the RH-WMA modified bitumen shows that the total SFE component of the base bitumen increases when higher amounts of RH-WMA was incorporated. The addition of $3.5 \%$ RH-WMA results in the highest SFE value of $24.98 \mathrm{~mJ} / \mathrm{m} 2$. The increase in the total SFE suggests good adhesion between the bitumen and the aggregates.
\end{abstract}

Keywords: Warm mix asphalt, response surface method, surface free energy, adhesion 


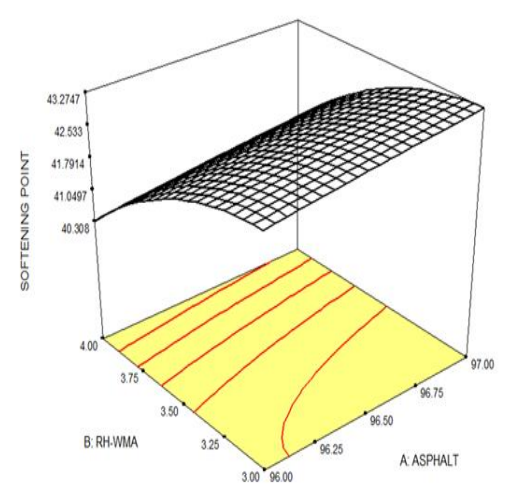

\begin{abstract}
Abstrak
Kajian ini bertujuan untuk menyiasat ciri-ciri kejuruteraan (cth. fizikal, kimia dan lekatan) bitumen bercampur aditif bitumen bersuhu sederhana (RH-WMA). Bitumen asli berpenusukan 80/100 dicampur dengan aditif RH-WMA sebanyak 3.0, 3.5 dan 4.0\% (mengikut jumlah berat bitumen). Kaedah Permukaan Sambutan di gunakan untuk mendapatkan nilai optimum bitumen asli dan aditif RH-WMA yang memenuhi spesifikasi bitumen dimana nilai penusukan dan titik lembut dipilih sebagai sambutan di dalam pelan susunatur rekabentuk. Tiga penyelesaian telah dipilih dari analisis kaedah permukaan sambutan sebagai nilai optimum iaitu 3.04, 3.55 \& $3.91 \%$ daripada aditif RH-WMA. Keputusan dari ujian fizikal menunjukkan penambahan aditif RH-WMA meningkatkan nilai penusukan dan ketahanan tetapi menurunkan nilai titik lembut. Analisis kelikatan pada suhu yang berbeza menunjukkan aditif RH-WMA menurunkan nilai kelikatan apabila suhu dinaikkan daripada $100^{\circ} \mathrm{C}$ ke $165^{\circ} \mathrm{C}$. Nilai kelikatan yang rendah memperbaiki kebolehkerjaan bitumen. Ujikaji Spektrometer Infra Merah menunjukkan tiada reaksi kimia yang kompleks berlaku di antara bitumen dan RH-WMA. Ujian Permukaan Bebas Tenaga dilakukan ke atas bitumen asli dan bitumen terubahsuai RH-WMA menunjukkan jumlah komponen permukaan bebas tenaga bagi bitumen asli meningkat apabila kuantiti RH-WMA bertambah. Penambahan 3.5\% RH-WMA memberi keputusan tertinggi bagi nilai permukaan bebas tenaga iaitu 24.98 $\mathrm{mJ} / \mathrm{m}^{2}$. Peningkatan nilai permukaan bebas tenaga menunjukkan lekatan yang kuat berlaku di antara bitumen dan aggregate.
\end{abstract}

Kata kunci: Bitumen suhu sederhana, kaedah permukaan sambutan, permukaan bebas tenaga, lekatan

(c) 2019 Penerbit UTM Press. All rights reserved

\subsection{INTRODUCTION}

One critical challenge that societies have to deal with is the environmental problems caused by the over-exploitation of natural resources and population growth, which ultimately results in the depletion of natural resources. Energy efficient technologies have been developed to deal with these problems, and some of these technologies are used to develop the asphalt mixtures used in road construction. For the past several years, the main material used in road construction is hot-mix asphalt (HMA). Hot-mix asphalt is produced at a high temperature and its production emits pollution, dust, particulate matter (PM), fumes, and an array of gases into the environment, such as carbon monoxide, nitrogen oxide, and sulphur dioxide [1]-[3] which contribute to the greenhouse effect.

Warm-Mix Asphalt (WMA) is an alternative technology developed to improve energy efficiency by reducing production temperature and emission. According to the Asphalt Institute, WMA is a modified HMA mixture that is produced, placed, and compacted at a temperature that is $10-40^{\circ} \mathrm{C}$ lower than the temperature required for conventional HMA mixture (which range between 140 and $180^{\circ} \mathrm{C}$ ) [4]. WMA is a green technology and it uses less burner fuel to heat the aggregates, reduces emission at the HMA plant, produces less polluting emissions, and has shorter asphalt aging during construction. These factors contribute to extending the life span of the road, and allow for earlier opening to traffic $[5,6]$.
Newly developed technologies, which use organic additives, chemical additives, and water-based or water-containing foaming processes, mean that WMA can now be manufactured and used at lower temperatures $[7,8]$. Even though WMA differs slightly from the other type of asphalt mixture, both mixtures seek to reduce the viscosity of asphalt. Reducing the viscosity of the asphalt mix improves its workability. This means better compaction and less roller pass is required to achieve the targeted density. The incorporation of WMA also improves workability at lower temperatures, which helps to extend the paving season, and allows for the asphalt mix to be transported over long distances without losing its workability for placement and compaction [9]. A new WMA additive, RH-WMA, has been manufactured to reduce the viscosity of asphalt binders at high temperatures, and to strengthen the structure of asphalt crystalline at low temperatures [10].

Bitumen is used in asphalt mixes to bind aggregates and to shift the stresses caused by traffic loading throughout the service life of the mixture [11]. SFE is used to investigate the adhesion and cohesion behaviour of asphalt mixtures from a mechanistic perspective. The degree of bonding between bitumen and aggregate is influenced by the ability of the asphalt to wet the aggregate [12]. The wettability of aggregates improves with smaller surface tension, or adhesion of Surface Free Energy (SFE) [13].

This paper focuses on investigating the physical, chemical, and adhesion properties of the base 
binder and RH-WMA modified bitumen. The optimum mixture content for bitumen and $\mathrm{RH}-\mathrm{WMA}$ additive with reference to the specification of the base binder was determined using the Response Surface Method (RSM). RSM is a group of statistical techniques used to design experiments, construct models, evaluate the effects of experimental factors, and improve procedures [14]. Many previous studies have used RSM as a tool for determining the optimal bitumen content in WMA [15, 16]. Fourier Transform Infrared Spectroscopy (FTIR) was used to identify the differences in the modified bitumen at different band areas $[17,18]$. Thermal analysis (TGA) and Differential Scanning Calorimetry (DSC) were conducted to identify the thermal behaviour of both types of samples. Adhesion test was performed to determine the work of adhesion under dry and wet conditions, work of cohesion, and energy ratio of both the base binder and the RH-WMA modified binders.

\subsection{METHODOLOGY}

\subsection{Materials}

The $80 / 100$ penetration grade base bitumen was obtained from Cenco Sains, a local bitumen factory in Port Klang, Malaysia. Table 1 presents the specifications for this bitumen. The RH-WMA, which is a liquid additive, was supplied by the Universal Pave Company based in China. This wax was developed by the Research Institute of Highway, Ministry of Transportation, China. RH-WMA is a polyethylene wax-based additive and is manufactured using crosslinked polyethylene. There are three types of $\mathrm{RH}$ WMA additives, and this study opted to use the $\mathrm{RH}$ WMA ES liquid additive since this additive has the ability to reduce the production temperature of asphalt by $30-60^{\circ} \mathrm{C}$.

Table 1 Physical properties of $80 / 100$ penetration grade bitumen

\begin{tabular}{|c|c|c|c|}
\hline Property & Specification & Test Method & Value \\
\hline \multicolumn{4}{|l|}{ Penetration } \\
\hline $\begin{array}{l}\text { at } 25^{\circ} \mathrm{C} \\
(\mathrm{dmm})\end{array}$ & $80-100$ & ASTM D5 & 88 \\
\hline $\begin{array}{l}\text { Softening } \\
\text { point }\left({ }^{\circ} \mathrm{C}\right)\end{array}$ & $45-52$ & ASTM D36 & 46 \\
\hline $\begin{array}{c}\text { Ductility at } \\
25^{\circ} \mathrm{C}\end{array}$ & Min 100 & ASTM DI13 & $>150$ \\
\hline $\begin{array}{c}\text { Viscosity at } \\
135^{\circ} \mathrm{C} \\
\text { (Pa.s) }\end{array}$ & - & ASTM D4402 & 0.388 \\
\hline Relative & & & \\
\hline $\begin{array}{l}\text { Density at } \\
25 / 25^{\circ} \mathrm{C}\end{array}$ & $1.00-1.05$ & ASTM D70 & 1.028 \\
\hline $\begin{array}{c}\text { Flash Point } \\
\left({ }^{\circ} \mathrm{C}\right)\end{array}$ & Min 225 & ASTM D92 & 290 \\
\hline
\end{tabular}

\subsection{Sample Preparation}

Three batches of $250 \mathrm{~g} 80 / 100$ base bitumen modified with varying percentages $(3,3.5$, and $4 \%$ ) of $\mathrm{RH}-\mathrm{WMA}$ additive by weight of base binder were heated. The mixtures were heated at $120^{\circ} \mathrm{C}$ for 15 minutes and mixed at 1500 rpm using a mechanical stirrer. Three important parameters, mixing rate, time, and temperature, were taken into consideration to ensure that the additives dissolve completely and form a homogeneous mixture with the base binder. In this study, the penetration and softening point values were used as indicators of a homogenous mixture and were monitored until stable results were obtained.

\subsection{Physical Properties Tests}

Physical tests were conducted on the base bitumen and RH-WMA modified bitumen to determine their penetration, softening point, and ductility properties as specified by the ASTM D5, ASTM D36, and ASTM D113, respectively. The storage stability of the RHWMA modified bitumen were measured as stipulated by the ASTM- D5926, which is an important test in determining whether the sample can be considered a storage stable blend. The three percentages of additives used for testing, i.e., $3,3.5$, and $4 \%$, were within the $3-4 \%$ recommended by the supplier.

\subsection{Response Surface Methodology (RSM)}

The Central Composite Design (CCD) was used to design the experimental layout, and is shown in Table 2. The experimental outcomes were run in the design matrix which looked at two independent variables, namely $96 \%$ to $97 \%$ bitumen (A) and $3 \%$ to $4 \% \mathrm{RH}-$ WMA additive (B). The results of the penetration and softening point tests were chosen as the responses (dependent variables). The proposed models for the volumetric behaviours are quadratic models. These analyses were run using the RSM Design-Expert 7.0 software.

Table 2 Layout of experimental design

\begin{tabular}{ccccc}
\hline \multirow{2}{*}{ Run } & \multicolumn{2}{c}{ Factor } & \multicolumn{2}{c}{ Response Parameter } \\
\cline { 2 - 5 } & $\begin{array}{c}\text { A: } \\
\text { Bitumen } \\
\text { \% }\end{array}$ & $\begin{array}{c}\text { B:RH- } \\
\text { WMA } \\
\text { \% }\end{array}$ & $\begin{array}{c}\text { Penetration } \\
\text { (dmm) }\end{array}$ & $\begin{array}{c}\text { Softening } \\
\text { Point } \\
\left(\mathbf{C}^{\circ}\right)\end{array}$ \\
\hline & & & & \\
1 & 97.00 & 3.00 & 158 & 43.3 \\
2 & 96.50 & 3.50 & 162 & 42.5 \\
3 & 96.50 & 3.50 & 162.7 & 42.3 \\
4 & 96.50 & 3.50 & 163.3 & 42.3 \\
5 & 96.00 & 4.00 & 177 & 40.2 \\
6 & 96.00 & 3.00 & 165.438 & 42.8 \\
7 & 96.00 & 3.50 & 167.33 & 42.1 \\
8 & 97.00 & 3.50 & 160.3 & 42.8 \\
9 & 96.50 & 4.00 & 176.27 & 40.9 \\
10 & 97.00 & 4.00 & 169.68 & 40.7 \\
11 & 96.50 & 3.50 & 162.3 & 42.4 \\
12 & 96.50 & 3.50 & 162.9 & 42.3 \\
13 & 96.50 & 3.00 & 161.2 & 42.9 \\
\hline
\end{tabular}




\subsection{Viscosity Test}

Viscosity test was performed to determine the resistance of the fluid to flow since it might affect the workability of the bitumen. The viscosities of the base bitumen and RH-WMA modified bitumen were measured using the Brookfield Viscometer at 100, 120, 135, and $165^{\circ} \mathrm{C}$ using spindle number 21 as stipulated in the ASTM D4402. Three optimum values of RH-WMA modified bitumen based on the results of the RSM were selected for this test.

\subsection{Morphological Observation}

The morphology of the samples was observed using the DINO-LITE Pro digital optical microscope, 500X. A small amount of heated base bitumen and RH-WMA modified bitumen were placed between two glass slides and viewed under the microscope.

\subsection{Fourier Transform Infrared (FTIR) Spectroscopy}

The FTIR spectrometer Perken Elmer-1650 manufactured in the US by Bruker Corporation was used to identify and quantify several chemical functional groups of interest in the bitumen which were modified with varying percentages of RH-WMA liquid at wavenumbers between $400 \mathrm{~cm}-1$ and 4000 $\mathrm{cm}-1$. The specimens were prepared by casting films onto Potassium Bromide $(\mathrm{KBr})$ which were then dried for the FTIR analysis.

\subsection{Thermal Gravimetric Analysis (TGA)}

The DSC test was done using the Shimadzu DSC-50 with compensatory power to obtain the thermograms of the bitumen modified with varying percentages of RH-WMA. All tests were done under nitrogen atmosphere using a sample mass of about 5 $\mathrm{mg}$ at a flow rate of $10 \mathrm{ml} / \mathrm{min}$; the temperature was increased from room temperature to $600{ }^{\circ} \mathrm{C}$ at a heating rate of $10{ }^{\circ} \mathrm{C} /$ minute. The sample for each test was sealed in an aluminum pan.

\subsection{Surface Free Energy (SFE)}

This test was carried out to determine the surface free energy (SFE) and work of adhesion in order to further identify the possible effect of RH-WMA additives on the performance of WMA. The Good-Van OssChaudhury theory states that based on the source of intermolecular force, SFE can decompose into three separate components. These components correspond with the monopolar acidic, Г+ monopolar basic, $\Gamma-$, , , and Lifshitz-van der Waals, or nonpolar component, $\Gamma \mathrm{LW}$. (Monopolar acidic and monopolar basic describe the polar component $A B$.) The component of a given material is calculated using Equation 1 and is used in this study to compute the SFE of bitumen surface.

$$
\Gamma=\Gamma_{A}^{L W}+2 \sqrt{\Gamma_{A}^{+} \Gamma_{A}^{-}}
$$

The specimens were prepared by coating a $25-\mathrm{mm}$ wide and 50-mm long standard cover glasses with bitumen. The bulk asphalt binder samples were heated at $105 \pm 5^{\circ} \mathrm{C}$ for an hour in the oven to melt the binders. The glass plates were then carefully dipped in the modified bitumen while they were still in the oven; this was repeated three times within 5 seconds to ensure that the bitumen completely coated the glass plates. The coated plates were left in the oven for 2 minutes in a vertical position to allow the excess bitumen to dribble, thereby producing a smooth surface. The samples were cured in a desiccator for 24 hours, after which the test was conducted. Measurement of the contact angle of the binder samples were made using three different probe liquids (water, Formamide, and Glycerol) by utilizing the Sessile Drop (SD) device. Equation 2 was then used to determine the SFE components of all bitumen and RH-WMA modified bitumen.

$$
\begin{aligned}
& \Gamma \mathrm{L}(1+\cos \theta)=2 \sqrt{\Gamma^{\mathrm{LW}}{ }_{\mathrm{A}}^{\mathrm{LW}}}+2 \sqrt{\Gamma^{+} \Gamma_{\mathrm{L}}^{-}} \\
& 2 \sqrt{\Gamma_{\mathrm{A}}^{-} \Gamma_{L}^{+}}
\end{aligned}
$$

Where $\zeta_{A}$ is the surface energy of the bitumen and $\Gamma_{L}$ is the surface energy (or surface tension) of the liquid. The work of adhesion under wet and dry conditions, work of cohesion, and energy ratio for the base bitumen and RH-WMA modified bitumen were then computed using the SFE components which has been determined earlier.

\subsection{RESULTS AND DISCUSSION}

\subsection{Physical Properties}

The results for the physical tests are summarized in Table 3. The 80/100 base bitumen modified with RHWMA showed higher penetration at room temperature, and the increased penetration is parallel with the increase in the percentage of $\mathrm{RH}$ WMA additive. The increase in the penetration values of the bitumen modified with $4 \%, 3.5 \%$, and $3 \% \mathrm{RH}-$ WMA are 88,77 and $69 \mathrm{~mm}$, respectively. The highest increase in penetration value was observed for the bitumen modified with $4 \%$ RH-WMA. The higher penetration values mean reduced stiffness of the bitumen. Additionally, the increased penetration, which suggests a decrease in the hardness of the bitumen, can be associated with the softening effect brought about by the addition of RH-WMA liquid to the base bitumen. Hamzah et al. [19] observed the same result when penetration was increased through the addition of RH-WMA to base bitumen. 
Table 3 presents the results for the softening point test. The temperatures for the softening point decreased with higher concentrations of RH-WMA. The higher penetration value and lower softening point of the RH-WMA modified bitumen indicate the softening effect of RH-WMA liquid. The ductility of the bitumen, however, was unaffected when the bitumen was modified with $\mathrm{RH}-\mathrm{WMA}$; both the base bitumen and the RH-WMA modified bitumen have ductility values higher than $160 \mathrm{~cm}$.

Table 3 Physical properties of base bitumen and RH-WMA modified bitumen

\begin{tabular}{cccc}
\hline & Penetration & $\begin{array}{c}\text { Softening } \\
\text { point }\end{array}$ & Ductility \\
\cline { 2 - 4 } $\begin{array}{c}\text { RH-WMA } \\
\text { concentration }\end{array}$ & $\mathbf{2 5}{ }^{\circ} \mathbf{C}, \mathbf{~ d m m}$ & ${ }^{\circ} \mathbf{C}$ & $\begin{array}{c}\mathbf{2 5}{ }^{\circ} \mathbf{C}, \\
\mathbf{~} \mathbf{m}\end{array}$ \\
\hline 0.0 \% RH-WMA & 89 & 45.3 & $>160$ \\
3.0\% RH-WMA & 158 & 43.3 & $>160$ \\
$3.5 \%$ RH-WMA & 162 & 42.5 & $>160$ \\
4.0\% RH-WMA & 177 & 40.2 & $>160$ \\
\hline
\end{tabular}

3.2 Effects on High-Temperature Storage Stability of Asphalt

Considering the attention given by previous researchers to the storage stability of modified bitumen, this study has also determined the storage stability of the modified bitumen [20 - 22]. The storage stability test was done on the RH-WMA modified bitumen to ensure that the blending process was effective, and that the samples are stable during storage. Table 4 presents the effects of storage stability of RH-WMA modified bitumen at hightemperatures. The RH-WMA modified bitumen showed good storage stability, with the difference in the values of the softening point for the top and bottom sections of the aluminum tube being less than $2.2{ }^{\circ} \mathrm{C}$. This indicates that the modified bitumen could remain stable during storage at high temperatures.

Table 4 Results for storage stability test of RH-WMA modified bitumen

\begin{tabular}{cc|ccc}
\hline & RH-WMA & \multicolumn{3}{|c}{$\begin{array}{c}\text { After Storage Stability test } \\
\text { Softening point }\left({ }^{\circ} \mathrm{C}\right)\end{array}$} \\
\cline { 3 - 5 } $\begin{array}{c}\text { RH- } \\
\text { WMA } \\
\%\end{array}$ & $\begin{array}{c}\text { modified } \\
\text { bitumen } \\
\text { Softening Point } \\
\left({ }^{\circ} \mathrm{C}\right)\end{array}$ & Top & Bottom & $\begin{array}{c}\text { Difference in } \\
\text { value }\end{array}$ \\
\hline 3.0 & 43.3 & 42.9 & 42.2 & 0.7 \\
3.5 & 42.5 & 41.0 & 41.9 & 0.9 \\
4.0 & 40.2 & 40.5 & 41.2 & 0.3 \\
\hline
\end{tabular}

\subsection{Results for Response Surface Methodology (RSM)}

\subsubsection{Analysis of Variance (ANOVA)}

The experimental results shown in Table 2 clearly show that the addition of higher percentage of $\mathrm{RH}$ WMA additive increased the penetration value and reduced the value of the softening point. The results for analysis of variance (ANOVA) for all volumetric parameters are presented in Table 5. The results show that for both the penetration and softening point parameters, the model term is significant since "Prob $>F^{\prime \prime}$ is less than 0.0500 (95\% confidence interval). The ANOVA analysis shows the quadratic models for coded factors, and characterizes other statistical parameters since it is crucial to verify the adequacy of the model. To verify the fitness of the model, the regression coefficients, $\mathrm{R} 2$ and $\mathrm{R} 2 \mathrm{adj}$, were computed, and the analysis shows that R2 is 0.9783 for penetration, and 0.9804 for softening point. High R2 and R2adj values suggest that there is reasonable agreement between the estimated and the actual values. The estimated R2 values are fairly congruent with the adjusted R2 values for all models, where R2pred is 0.8327 and R2adj is 0.9628; for the softening point, the R2pred is 0.8395, which is reasonably consistent with the R2adj of 0.9663 . Another way of verifying the adequacy of the model is by looking at the value of the Lack of Fit (LOF). This is because the discrepancy of data around the fitted model is described by the LOF. As can be seen in Table 5, the LOF values for the penetration and softening points are significant $(p<0.05)$. Therefore, the estimate for the response is within the defined experimental range, and can be used since the estimated model conforms well to the experimental data.

In this analysis, the A, B and B2 are significant for the penetration and softening points, but $A 2$ and $A B$ have a ( $p>0.05)$, which indicate that the model term is not significant, and is used to support hierarchy [23]. The evaluation of model prediction of RSM-CCD should be examined by evaluating adequate precision (AP). A signal to noise ratio exceeding 4 is preferred since an adequate level of AP provides a measurement of the signal to noise ratio. The results show that the ratios are 26.09 for penetration and 25.51 for softening point. This shows that the model is adequate for navigating the design criteria. The fitted quadratic polynomial equations are as follows:

$$
\begin{aligned}
& \text { Penetration }=+162.97-3.63 \mathrm{~A}+6.39 \mathrm{~B}+0.026 \mathrm{~A}^{2}+4.95 \\
& \mathrm{~B}^{2}+0.030 \mathrm{AB} \\
& \begin{array}{l}
\text { Softening point }=+42.39+0.28 \mathrm{~A}-1.20 \mathrm{~B}-0.026 \mathrm{~A}^{2}-0.58 \\
\mathrm{~B}^{2}
\end{array} \\
& \begin{array}{l}
\text { Softening point }=+42.39+0.28 \mathrm{~A}-1.20 \mathrm{~B}-0.026 \mathrm{~A}^{2}-0.58 \\
\mathrm{~B}^{2}
\end{array}
\end{aligned}
$$

In both Equations (3) and (4), A corresponds to the independent factors of base bitumen and $B$ corresponds to the RH-WMA additive. 


\subsubsection{Effects of Parameters (Analysis of RSM)}

Surface plots are usually very useful in determining any probable relations that might exist between factors. Two predictor factors are plotted on the $x$ and $y$-axes while the response variable is plotted in the $z$ direction in the form of a smooth surface known as surface plot. Contours and surface plots can be used in conjunction with the set up polynomial relationship between response and factors to study the dependency of response on factors.

Table 5 Analysis of ANOVA for response

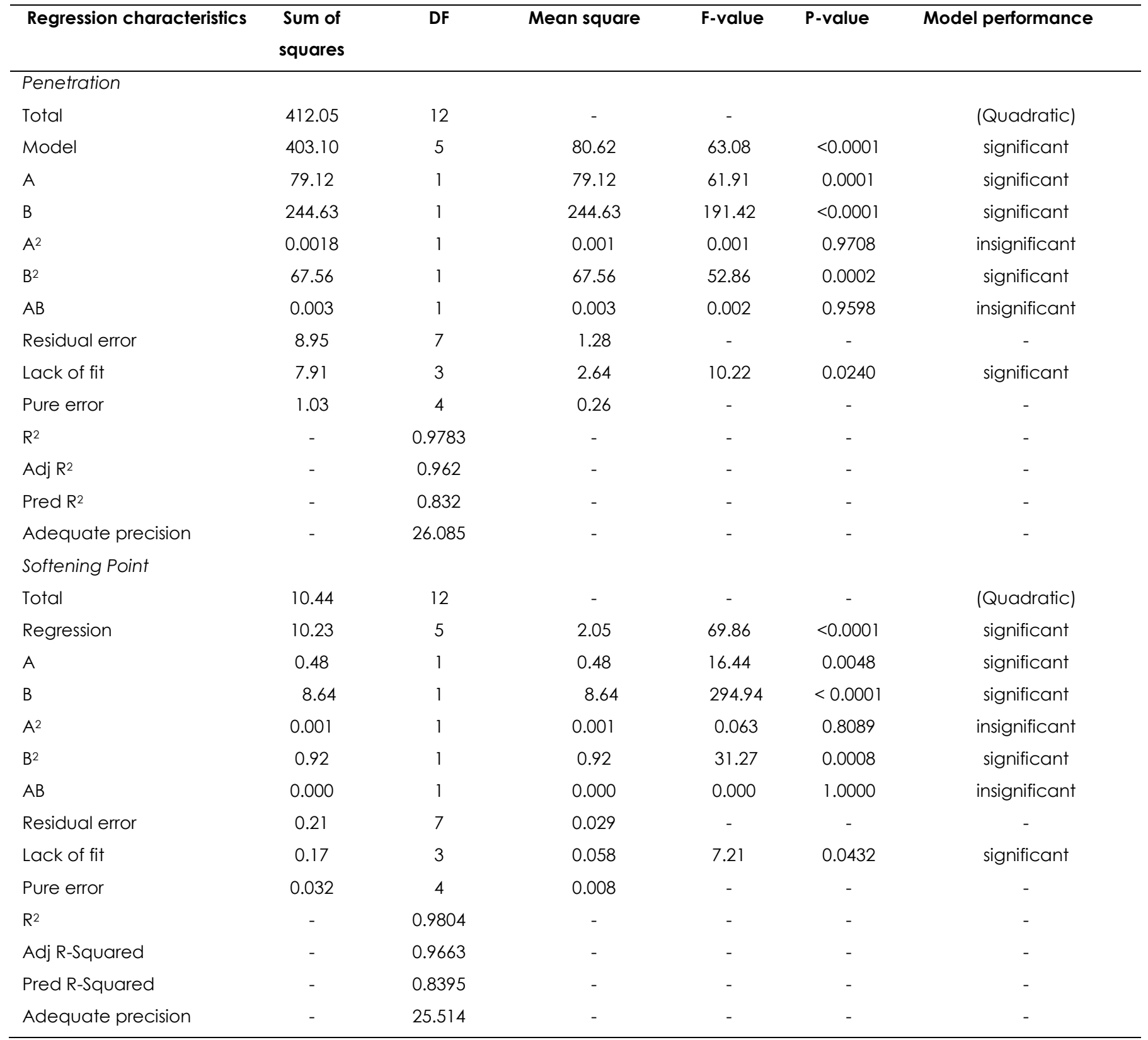

Figure 1(a) shows the curvature of the surface plotted for penetration; the plot suggests that the bitumen and the RH-WMA interacted with each other during penetration. It also shows that maximum penetration occurred at a high RH-WMA content of $4 \%$. The curvature of the surface plot for softening point shown in Figure 1 (b) suggests that the bitumen and the RH-WMA additive interacted with each other at the softening point. The minimum softening point occurred at a high RH-WMA content of $4 \%$, and a low bitumen content of $96 \%$. A contour plot can be used to identify the relationships between three variables in one plot. Figures $2(a)$ and (b) show the contour plot of RH-WMA additive and bitumen content versus the results of the penetration and softening point tests. These graphs clearly show that 
penetration increased while the softening point decreased as the content of RH-WMA was increased from 3 to $4 \%$, and when asphalt content was reduced from $97 \%$ to $96 \%$.

\subsubsection{Numerical Optimization of the Process Response}

One of the primary objectives of this study is to identify the optimum percentage of RH-WMA and bitumen content within the calculated experimental range conducted by using the point prediction function in the Design-Expert software. The results suggest 10 solutions for bitumen and RH-WMA content and the software proposed these as the optimum values for meeting the requirements of the design. Of the 10 solutions, three were chosen for further analysis based on the results of chemical and adhesion tests, and were then verified through laboratory test for penetration and softening point, as shown in Table 6. The optimal conditions can be presented in a graphical form by overlapping the contours of the response surfaces in an overlay plot, as shown in Figure 3. Based on the plot obtained, the software suggested that $96.94 \%$ bitumen and $3.55 \%$ $\mathrm{RH}-\mathrm{WMA}$ are the optimum percentages for meeting the requirements of the design.

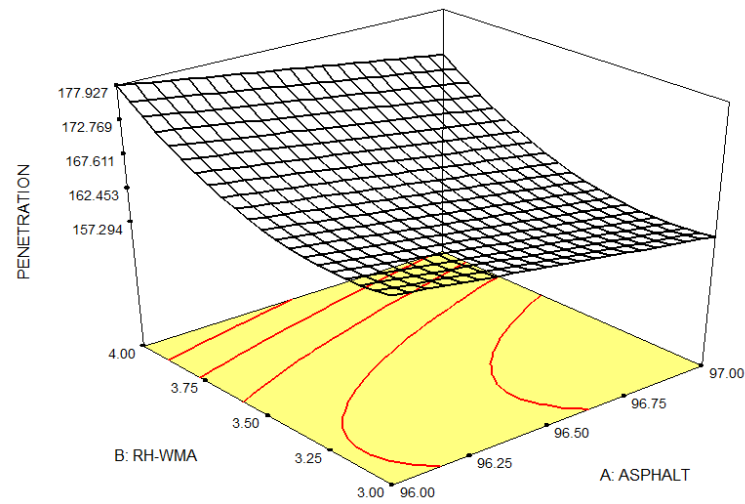

(a)

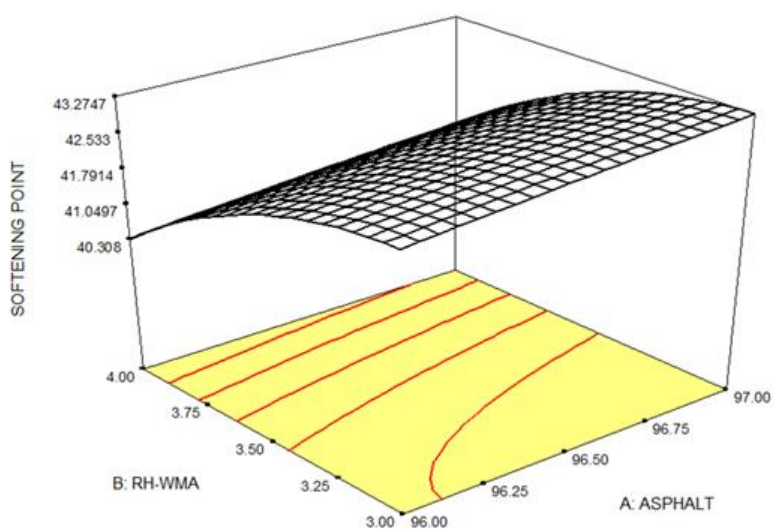

(b)

Figure 1 Surface plots of (a) Penetration, and (b) Softening point versus RH-WMA and bitumen content

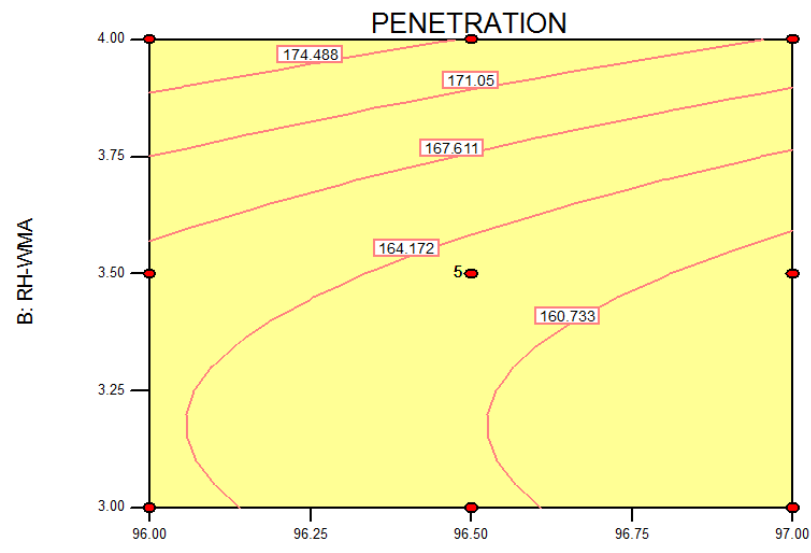

A: ASPHALT

(a)

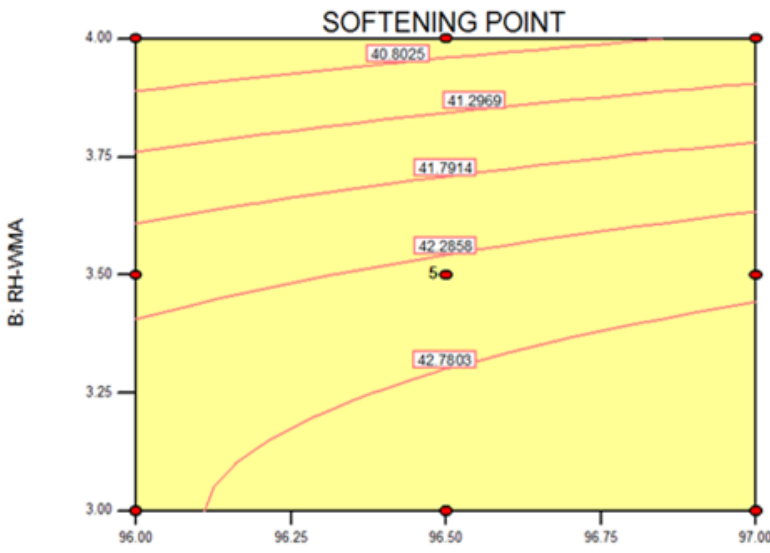

(b)

Figure 2 Contour plots of (a) Penetration, and (b) Softening point versus RH-WMA and bitumen content

Table 6 Optimum combination of binder and RH-WMA

\begin{tabular}{ccccc}
\hline & Bitumen & RH- & & \\
No & $80 / 100$ & WMA & Penetration & Softening Point \\
& $(\%)$ & Additive & $(\mathrm{dmm})$ & $\left({ }^{\circ} \mathrm{C}\right)$ \\
& & $(\%)$ & &
\end{tabular}

\begin{tabular}{ccccccc}
\hline & & & RSM & Laboratory & RSM & Laboratory \\
\hline 1 & 96.39 & 3.91 & 158.9 & 157.3 & 43.2 & 42.8 \\
2 & 96.82 & 3.04 & 160.4 & 159.7 & 42.5 & 42.3 \\
3 & 96.94 & 3.55 & 172.2 & 171.8 & 40.5 & 40.2
\end{tabular}




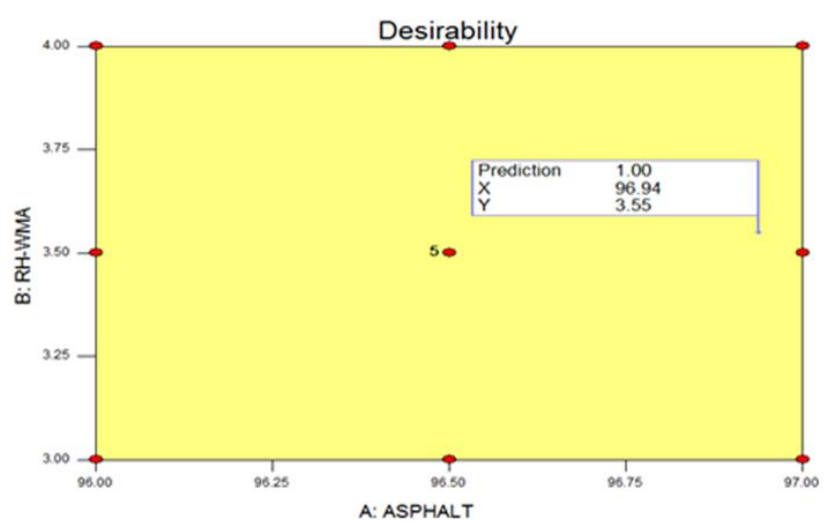

Figure 3 Optimum conditions for bitumen and RH-WMA

\subsection{Viscosity Test at Varying Temperature}

The viscosities of the base bitumen and RH-WMA modified bitumen were measured using the Brookfield Viscometer at $100^{\circ} \mathrm{C}, 120^{\circ} \mathrm{C}, 135^{\circ} \mathrm{C}$ and $165^{\circ} \mathrm{C}$, and the measurements are plotted in Figure 4. The plot shows that the addition of RH-WMA liquid to the base bitumen decreased the viscosity of the bitumen at the desired temperature. For example, the viscosity at $120^{\circ} \mathrm{C}$ with maximum composition decreased from 0.805 to $0.488 \mathrm{~Pa}-\mathrm{s}$, while the addition of RH-WMA decreased the mixing temperature by about $39.3 \%$. At $120^{\circ} \mathrm{C}$, the addition of $3.04,3.55$ and 3.91 RH-WMA decreased the viscosity by $23.22 \%, 33.7 \%$ and $39.3 \%$, respectively. Smaller reduction in viscosity was observed as the temperature was increased. The viscosity of the bitumen at $135^{\circ} \mathrm{C}$ is $0.372 \mathrm{~Pa}-\mathrm{s}$. The temperatures required for the RH-WMA samples to achieve a viscosity of $0.372 \mathrm{~Pa}-\mathrm{s}$ are $126^{\circ} \mathrm{C}, 123^{\circ} \mathrm{C}, 121^{\circ} \mathrm{C}$ for the 3.04\% RH-WMA, 3.55\% RH-WMA and 3.91\% RH-WMA samples, respectively. Thus, a reduction of $14^{\circ} \mathrm{C}$ at $135^{\circ} \mathrm{C}$ was predicted for $3.91 \%$ RH-WMA. These results are similar to those obtained by Gungat et al. [24], where the addition of RH-WMA resulted in lower binder viscosity and the mixing temperature was reduced to $20^{\circ} \mathrm{C}$. Gungat et al. [25] also conducted a study using RH-WMA and the results of their study showed that viscosity decreased with higher temperature, and the viscosity of the bitumen was significantly altered at lower temperature. These results have been confirmed in field studies. Lower viscosity could improve the workability of RH-WMA modified bitumen.

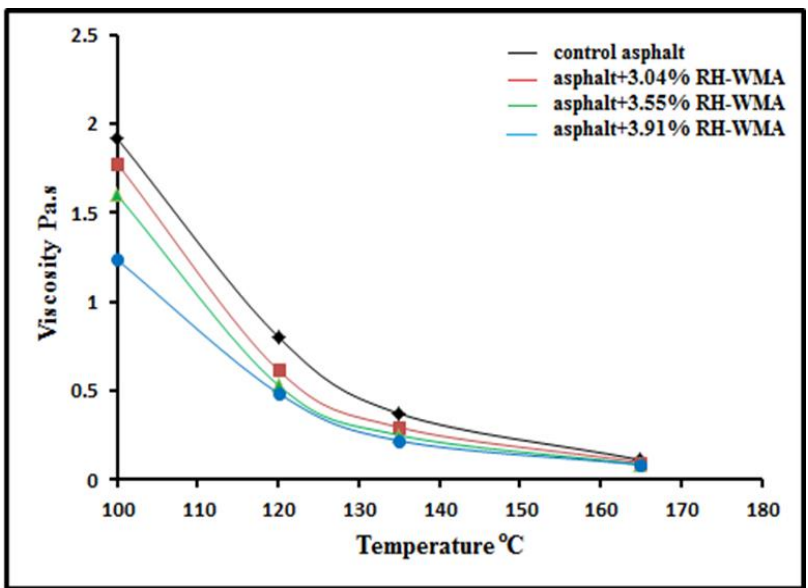

Figure 4 Rotational viscosity of control base bitumen and optimum RH-WMA modified bitumen

\subsection{Chemical Analysis}

\subsubsection{Fourier Transform Infrared (FTIR)}

Figure 5 shows the FTIR spectra of the bitumen modified with different percentages of RH-WMA. It shows that even though the peak values for the base and modified bitumen are different, they both have typical absorption peaks at similar wavenumbers. The major bands at $2910 \mathrm{~cm}-1$ are the typical $\mathrm{C}-\mathrm{H}$ stretching vibrations of hydrocarbons - $\mathrm{CH} 2$-. The absorption peaks at $1610 \mathrm{~cm}-1$ is due to the $\mathrm{C}=\mathrm{C}$ bond in the benzene ring and the $\mathrm{C}=\mathrm{O}$ bond in aromatic hydroxyl. The bending vibrations of - $\mathrm{CH} 2-$ and -CH3- groups happen at $1446 \mathrm{~cm}-1$ and 1362 $\mathrm{cm}-1$, respectively. The observed absorption band at about 1045-1055 cm-1 is due to the stretching vibration of the sulfoxide group $(S=O)$ in the bitumen. The fingerprint region at $730-800 \mathrm{~cm}-1$ is the benzene replacement area. Here, the absorption peaks is due to the vibration of $=\mathrm{CH} 2$ bond and the swing in benzene ring, as well as the in-plane swing of $[\mathrm{CH} 2] \mathrm{n}-(\mathrm{n}>4)$ in alkyl. A comparison of the FTIR spectra for the base bitumen and the RH-WMA modified bitumen shows that there is no complex chemical reaction between the additive and bitumen, although there is an apparent effect on the chemical bonds of the different components. Since the structure of RH-WMA (polyethylene wax) is [CH2]n-, there are greater relative intensities of bands near $2910 \mathrm{~cm}-1$ (due to stretching vibrations of - $\mathrm{CH} 2-$ ), and $1446 \mathrm{~cm}-1$ (due to bending vibrations of $-\mathrm{CH} 2-$ ) in the range of RH-WMA compared to those of the base bitumen. Although the differences are slight due to the sensitivity of the FTIR, the changes indicate that the RH-WMA additive has been successfully incorporated into the base bitumen. 


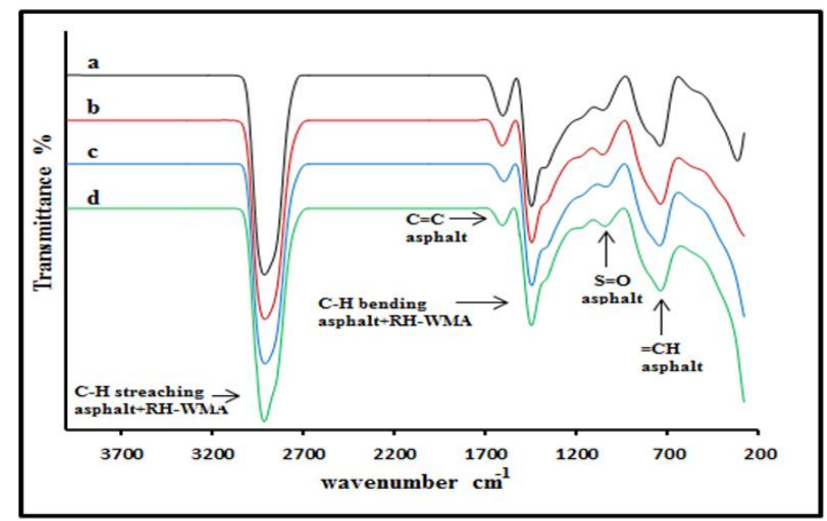

Figure 5 FTIR spectra of (a) Base bitumen, (b) $3.04 \% \mathrm{RH}$ WMA, and (c) $3.55 \%$ RH-WMA and $3.91 \%$ RH-WMA

\subsubsection{TGA and DSC Test}

TGA and DSC thermal analyses of the base bitumen and the RH-WMA modified bitumen were carried out to further understand the thermal behaviour of the whole system. The TGA curves of the base bitumen and those modified with $3.04 \%, 3.55 \%$ and $3.91 \% \mathrm{RH}-$ WMA are presented in Figure 6. This figure shows that the trends of the TGA curves for the base bitumen and the RH-WMA-modified bitumen are almost the same. It is obvious that temperature ranges for the base bitumen and the RH-WMA are comparable for the main decomposition (approximately $250-450{ }^{\circ} \mathrm{C}$ ), which indicate the limited effect of the addition of RH-WMA liquid on thermal stability. Figure 6 also shows that the weight loss in RH-WMA modified bitumen was higher than that of the base bitumen at temperatures exceeding $450{ }^{\circ} \mathrm{C}$. The higher weight loss of RH-WMA at higher temperature $\left(>450^{\circ} \mathrm{C}\right)$ can be attributed to the high degradation in the aliphatic main chain of the polyethylene wax -[CH2]n-, which occurred because the aliphatic organic compounds in the binder, such as polyethylene, were less stable than the aromatic organic compounds. In addition, the increase in weight loss was expected based on the fact that the introduction of RH-WMA as a liquid additive reduced the stiffness of the mixture.

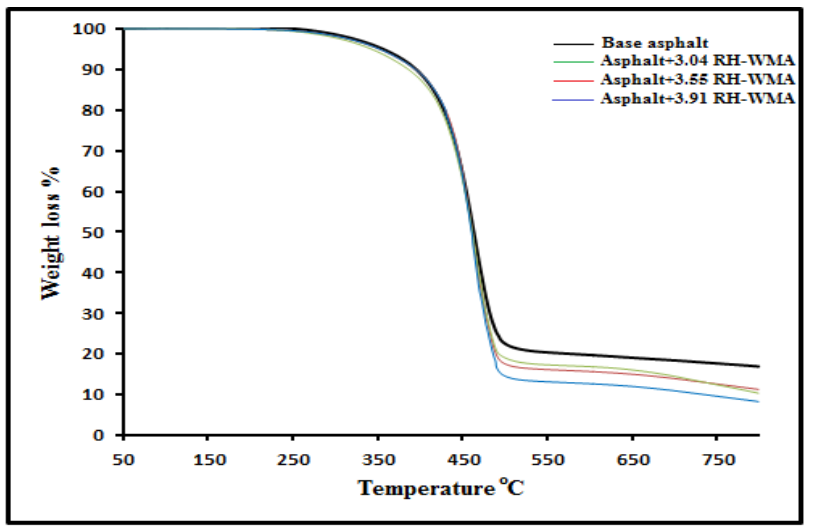

Figure 6 TGA thermograms of base bitumen and optimum RH-WMA modified bitumen
Out of the three RH-WMA modified bitumen samples, the bitumen modified with $3.04 \%$ and $3.55 \%$ RH-MWA showed similar patterns in their TGA curves. A distinct difference was observed in the bitumen modified with $3.91 \%$ RH-WMA, where the sample lost more components than the other modified bitumen at high temperatures. The TGA curves for the base and RH-WMA modified bitumen systems show several distinct characteristics, including initial decomposing temperature (Ti), temperature related to the half mass loss (T50\%), and final residue mass ratio (Mf) at $800^{\circ} \mathrm{C}$, all of which are listed in Table 7.

Table 7 Thermal data of base bitumen and RH-WMA modified bitumen

\begin{tabular}{llllll}
\hline Component & $\mathbf{T}_{\mathbf{g}}{ }^{\circ} \mathbf{C}$ & $\mathbf{T}_{\mathbf{m}}{ }^{\circ} \mathbf{C}$ & $\begin{array}{l}\mathbf{T}_{\mathbf{i}} \\
{ }^{\circ} \mathbf{C}\end{array}$ & $\mathbf{T}_{50 \%}{ }^{\circ} \mathbf{C}$ & $\begin{array}{l}\mathbf{M}_{\mathbf{f}} \\
\%\end{array}$ \\
\hline Base bitumen & 31 & 100 & 225 & 463 & 16.1 \\
3.04 \% RH WMA & 28 & 92 & 223 & 461 & 10.4 \\
3.55 \% RH-WMA & 27 & 86 & 222 & 460 & 11.2 \\
3.91\% RH-WMA & 25 & 81 & 220 & 459 & 8.3 \\
\hline
\end{tabular}

The DSC curves of the base bitumen and RH-WMA modified bitumen are presented in Figure 7 . It shows that the glass transition, $\mathrm{Tg}$, and melting point, Tm, of the base bitumen are higher than those of the RHWMA modified bitumen. In addition, the Tg and Tm of RH-WMA modified bitumen decreased with higher percentages of RH-WMA. This decrease is associated with the fact that $\mathrm{Tg}$ and $\mathrm{Tm}$ decreased with reduced stiffness and aromaticity (as described in section 3.1). Table 8 presents the values for the Tg and $\mathrm{Tm}$ of the base bitumen and RH-WMA modified bitumen. The DSC plots clearly show that there is a slight difference between the curves for the base and the RH-WMA modified bitumen. There is a slight difference in the initiation of the thermal degradation temperature between the base and the RH-WMA modified bitumen, which indicate that RH-WMA increased the thermal degradation of the bitumen constituent efficiently.

Table 8 Contact angles of base bitumen and RH-WMA modified bitumen

\begin{tabular}{c|c|c|c}
\hline \multirow{2}{*}{$\begin{array}{c}\text { Additive Content } \\
\text { (RH- WMA) }\end{array}$} & \multicolumn{3}{|c}{ Contact Angles (Degrees) } \\
\cline { 2 - 4 } & Water & Formamide & Glycerol \\
\hline $0.00 \%$ & 84 & 77.1 & 83.1 \\
$3.04 \%$ & 81.2 & 74.2 & 80.3 \\
$3.55 \%$ & 76.1 & 73 & 78.8 \\
$3.91 \%$ & 73.8 & 72.7 & 76.4 \\
\hline
\end{tabular}




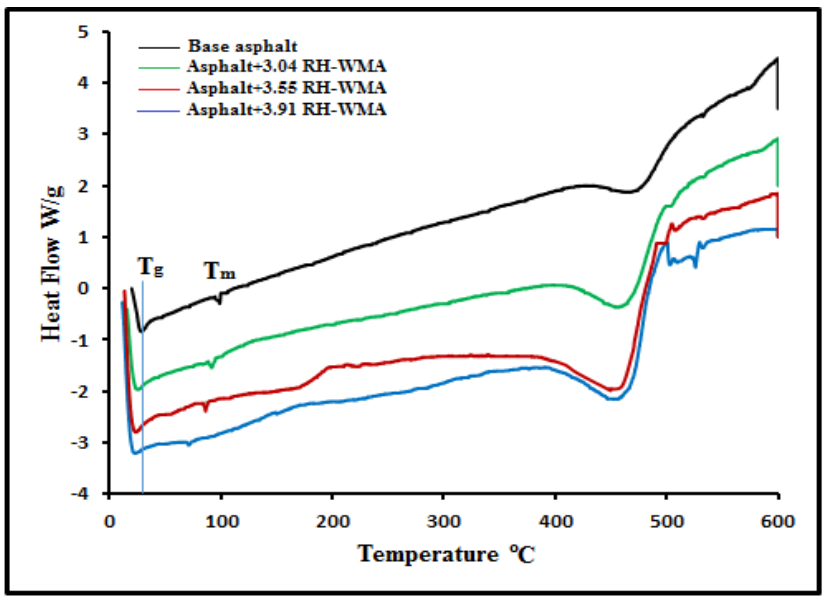

Figure 7 DSC curves of base bitumen and RH-WMA modified bitumen

\subsection{Optical Microscopy Analysis}

The morphologies of the base bitumen and the $\mathrm{RH}-$ WMA modified bitumen were explored using optical

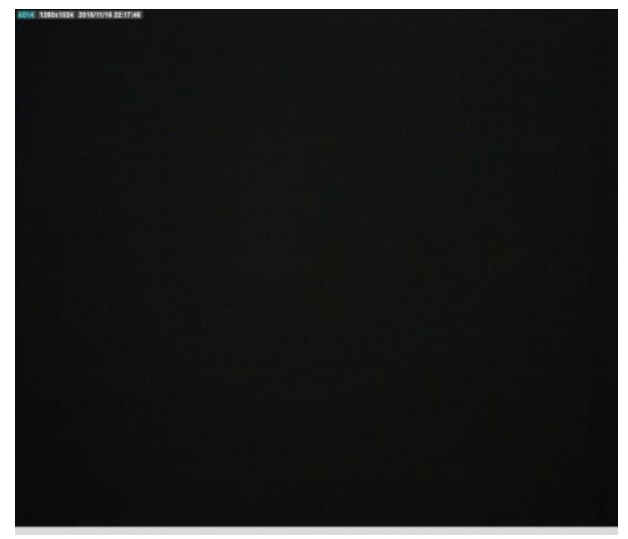

(a) Base binder

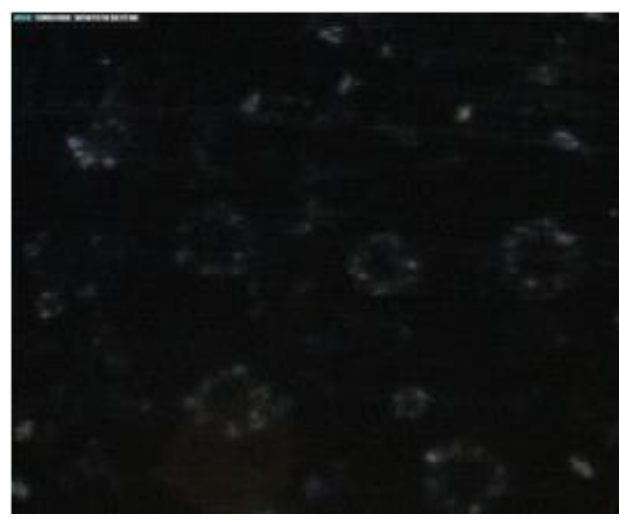

(c) $3.55 \%$ RH-WMA microscopy. This was done to investigate the microstructure interaction between the bitumen and the additive by determining the distribution of $\mathrm{RH}$ WMA in the bitumen. The rich phase of the base bitumen appears dark or black, whereas the rich phase of the RH-WMA appears white. The images of the base bitumen and the bitumen modified with varying percentages of RH-WMA are shown in Figure 8. The image of the base bitumen is generally dark black, as can be seen in Figure 8(a), while the binder modified with $3.04 \%$ RH-WMA shows little white spots, as can be seen in Figure 8(b). The images in Figures 8 (c) and (d) show that the amount of RH-WMA added to the bitumen had a profound effect on the microstructures of the modified bitumen; bitumen with higher amounts of RH-WMA show better morphology at the boundary of the white spots and the dark areas are more discernible, dispersed, and clear with the liquid additive clearly overlapping the bitumen. The morphologies of the mixtures clearly show the formation of homogeneous, warm mixtures.

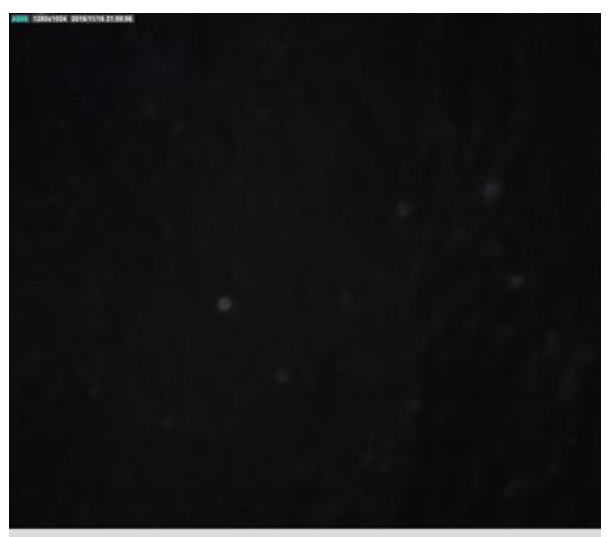

(b) $3.04 \%$ RH-WMA

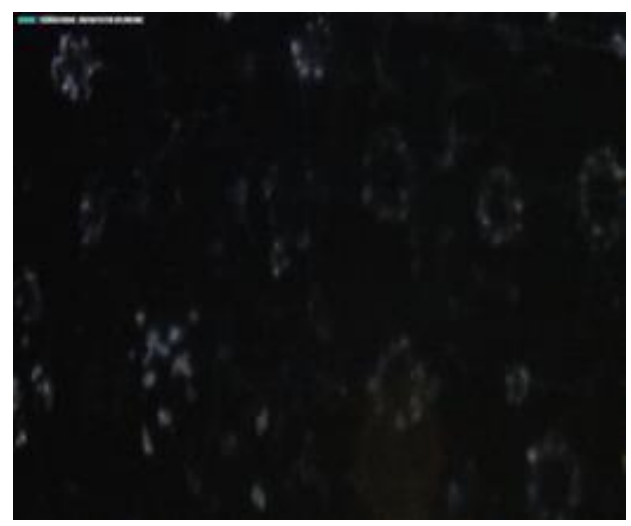

(d) $3.91 \%$ RH-WMA

Figure 8 Optical microscopy for base bitumen and RH-WMA modified bitumen 


\subsection{Surface Free Energy (SFE)}

In this study, the surface free energy (SFE) components of the base bitumen and the RH-WMA modified bitumen were calculated using the Goodvan Oss-Chaudhury (GVOC) approach, as given by Equation 2. This equation contains four known surface energy components of the probe liquid (โL, [LLW, 「L-, and $[\mathrm{L}+)$ as presented in Table 8 , and three unknown surface energy components of the solid (i.e., [ALW, $\left\lceil A+\right.$, and $\left(\mathrm{A}_{-}\right)$and the contact angle $(\theta)$ terms. The contact angles of the base bitumen and the $\mathrm{RH}$ WMA modified bitumen were measured using a sessile drop (SD) device utilizing three different probe liquids (i.e., water, Formamide and Glycerol). Table 9 presents the values of the average contact angle for all samples.

Table 9 Components of surface energy of three liquid probes $(\mathrm{mJ} / \mathrm{m} 2)$

\begin{tabular}{c|ccccc}
\hline \multirow{2}{*}{$\begin{array}{l}\text { Liquid } \\
\text { Probe }\end{array}$} & $\Gamma^{\text {Total }}$ & $\boldsymbol{\Gamma}^{\mathrm{LW}}$ & $\boldsymbol{\Gamma}^{\mathrm{AB}}$ & $\boldsymbol{\Gamma}^{-}$ & $\boldsymbol{\Gamma}^{+}$ \\
\cline { 2 - 6 } & \multicolumn{5}{|c}{$\mathbf{m ~ J / m 2}$} \\
\hline Water & 72.80 & 21.80 & 51.00 & 25.50 & 25.50 \\
Formamide & 58 & 39 & 30.00 & 39.6 & 2.28 \\
Glycerol & 64.00 & 34.00 & 30.00 & 57.40 & 3.92 \\
\hline
\end{tabular}

The computed SFE components of the base bitumen and the RH-WMA modified bitumen are presented in Table 10. They show that the bitumen's total SFE component ([ Total) increased with the addition of higher amounts of RH-WMA. The maximum increase in the value of the total SFE component was observed for the bitumen modified with $3.55 \%$ RH-WMA. The higher total SFE indicates good adhesion of the bitumen with the aggregates [26].

Table 10 SFE components of base bitumen and RH-WMA modified bitumen

\begin{tabular}{|c|c|c|c|c|c|}
\hline \multirow{2}{*}{$\begin{array}{c}\text { Additive } \\
\text { Content } \\
\text { (RH- } \\
\text { WMA) }\end{array}$} & [Total & $\Gamma^{\text {IW }}$ & $\Gamma \mathrm{AB}$ & $\begin{array}{c}\Gamma \\
\text { (Base) }\end{array}$ & $\begin{array}{c}\Gamma^{+} \\
\text {(Acid) }\end{array}$ \\
\hline & \multicolumn{5}{|c|}{$(\mathrm{mJ} / \mathrm{m} 2)$} \\
\hline $0 \%$ & 22.41 & 19.35 & 3.06 & 0.20 & 11.90 \\
\hline $3.04 \%$ & 24.10 & 20.37 & 3.73 & 0.26 & 13.13 \\
\hline $3.55 \%$ & 24.98 & 21.14 & 3.83 & 0.20 & 18.74 \\
\hline $3.91 \%$ & 24.50 & 14.93 & 9.57 & 1.08 & 21.24 \\
\hline
\end{tabular}

\subsubsection{Work of Adhesion}

Work of adhesion is a measure of the work which has to be done to separate the two materials at their interface. Therefore, the SFE components of the aggregate and the bitumen have to be determined prior to calculating the work of adhesion of a mixture. Table 10 presents the calculated SFE components for the bitumen, while Table 11 presents the SFE components for two Oklahoma aggregates (i.e., Davis limestone and Snyder granite) which were calculated using the data for the contact angle obtained from using the SD device in the study conducted by KOC [27]. Once the SFE components of both the bitumen (A) and the aggregate (S) have been quantified, the work of adhesion between the two materials (in the absence of water at the interface) was computed using Equation 5.

Table 11 SFE components of Davis Limestone and Snyder Granite determined in a study conducted by Koc [27]

\begin{tabular}{c|c|c|c|c|c}
\hline \multirow{2}{*}{$\begin{array}{c}\text { Aggregate } \\
\text { Type }\end{array}$} & $\lceil$ Total & $\Gamma^{\mathrm{Lw}}$ & $\Gamma^{\mathrm{AB}}$ & $\Gamma^{*}$ & $\Gamma^{+}$ \\
\cline { 2 - 7 } & \multicolumn{5}{|c}{$\mathbf{m J} / \mathbf{m} 2$} \\
\hline Davis Limestone & 37.61 & 36.26 & 1.35 & 10.12 & 0.05 \\
Snyder Granite & 34.66 & 34.39 & 0.28 & 13.97 & 0.01 \\
\hline
\end{tabular}

(5)

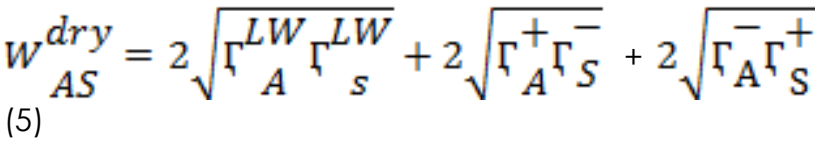

Table 12 presents the work of adhesion between two types of aggregates with the base bitumen and the RH-WMA modified bitumen under dry condition. Based on the data, the addition of RH-WMA increased the work of adhesion. Higher work of adhesion means a stronger bond between the components of the asphalt mix, resulting in a durable mixture that is less susceptible to moisture. Hence, the addition of RH-WMA modified bitumen to the mixtures manufactured using both acidic and basic aggregates is expected to result in improved durability of the mixtures in addition to better resistance to moisture-induced damage.

Table 12 Work of adhesion/cohesion and ER of Davis Limestone (DL) and Snyder Granite (SG) combined with base bitumen and RH-WMA modified bitumen

\begin{tabular}{c|cccc}
\hline \multirow{2}{*}{$\begin{array}{c}\text { Aggregate- } \\
\text { bitumen }\end{array}$} & $\begin{array}{c}\text { Work } \\
\text { of } \\
\text { cohesi } \\
\text { on }\end{array}$ & $\begin{array}{c}\text { Work of } \\
\text { adhesi } \\
\text { on } \\
\text { (Dry) }\end{array}$ & $\begin{array}{c}\text { Work of } \\
\text { Debondi } \\
\text { ng (Wet) }\end{array}$ & $\begin{array}{c}\text { Ener } \\
\text { gy } \\
\text { Ratio } \\
\text { (ER })\end{array}$ \\
\cline { 2 - 5 } & \multicolumn{4}{c}{ (ergs/cm2 or mJ/m2) } \\
\hline DL-Control & 44.83 & 75.13 & 49.70 & 1.51 \\
DL-3.04\% RH-WMA & 48.2 & 77.65 & 48.69 & 1.59 \\
DL-3.55\% RH-WMA & 49.95 & 83.12 & 46.97 & 1.77 \\
DL-3.91\% RH-WMA & 49.00 & 76.32 & 38.19 & 2.00 \\
SG-Control & 44.83 & 77.47 & 49.15 & 1.58 \\
SG-3.04\% RH-WMA & 48.2 & 80.13 & 48.27 & 1.66 \\
SG-3.55\% RH-WMA & 49.95 & 86.38 & 47.33 & 1.83 \\
SG-3.91\% RH-WMA & 49.00 & 79.98 & 38.94 & 2.05 \\
\hline
\end{tabular}




\subsubsection{Work of Debonding}

Work of debonding ( $W_{\text {Ners }}^{\text {wer }}$ ), which is the work of adhesion under wet conditions, is another vital energy parameter. It is defined as a decrease in the free energy of bitumen and an aggregate system when bitumen is separated from aggregate at their interface in the presence of water. The work of adhesion between bitumen and aggregate in the presence of water (W) was computed using Equation 6.

$$
\mathrm{W}_{\mathrm{ASW}}^{\text {wet }}=2\left[\begin{array}{l}
\sqrt{\Gamma_{\mathrm{A}}^{\mathrm{LW}} \Gamma_{\mathrm{W}}^{\mathrm{LW}}}+\sqrt{\Gamma_{\mathrm{S}}^{\mathrm{LW}} \Gamma_{\mathrm{W}}^{\mathrm{LW}}}-\sqrt{\Gamma_{\mathrm{A}}^{\mathrm{LW}} \Gamma_{\mathrm{S}}^{\mathrm{LW}}}-\Gamma_{\mathrm{w}}^{\mathrm{LW}} \\
+\sqrt{\Gamma_{\mathrm{W}}^{+}}\left\{\sqrt{\Gamma_{\mathrm{A}}^{-}}+\sqrt{\Gamma_{\mathrm{S}}^{-}}-\sqrt{\Gamma_{\mathrm{W}}^{-}}\right\} \\
+\sqrt{\Gamma_{\mathrm{W}}^{-}}\left\{\sqrt{\Gamma_{\mathrm{A}}^{+}}+\sqrt{\Gamma_{\mathrm{S}}^{+}}-\sqrt{\Gamma_{\mathrm{W}}^{+}}\right\}+\sqrt{\Gamma_{\mathrm{A}}^{+} \Gamma_{\mathrm{S}}^{-}}+\sqrt{\Gamma_{\mathrm{A}}^{-} \Gamma_{\mathrm{S}}^{+}}
\end{array}\right]
$$

Table 12 shows the work of debonding between two types of aggregates with the base bitumen and the RH-WMA modified bitumen. Results indicate that the addition of RH-WMA reduced the work of debonding. The maximum required effect occurred when $3.91 \% \mathrm{RH}-\mathrm{WMA}$ was added to the bitumen. Adding $3.91 \% \mathrm{RH}-\mathrm{WMA}$ to the chosen bitumen and Snyder granite aggregate resulted in a maximum reduction $(25 \%)$ of the work of debonding in comparison to that of the base bitumen, which is desired when the concern is to reduce the resistance of moisture-induced damage. Higher work of debonding implies a higher thermodynamic potential for stripping to occur in the presence of water.

\subsubsection{Work of Cohesion}

Work of cohesion is the energy produced by two new surfaces in a homogeneous material, and this value is twice that of the surface free energy. Work of cohesion was calculated using Equation 7.

$$
W A A=2 \Gamma_{A}^{L W}+4 \sqrt{\Gamma_{A}^{-} \Gamma_{A}^{+}}
$$

Table 12 shows the work of cohesion of the base bitumen and the RH-WMA modified bitumen. It shows that the addition of RH-WMA increased the value of the work of cohesion of both the base bitumen and the RH-WMA modified bitumen, with the modified bitumen showing better cohesion. Higher work of cohesion shows that more work is required to fracture the material.

\subsubsection{Energy Ratio}

Energy ratio (ER) is a parameter related to the potential for moisture-induced damage in bituminous pavements. Comparison of the resistance of aggregate-binder to moisture-induced damage was done using the Energy Ratio (ER) approach given by
Equation 8. The ER for Davis Limestone (DL) and Snyder Granite (SG) with the base bitumen and for the RH-WMA modified bitumen were calculated and are presented in Table 12.

$$
E R_{1}=\frac{W_{\text {AS }}^{\text {dry }}}{W_{\text {ASW }}^{\text {wet }}}
$$

The values presented in Table 12 show that using RH-WMA modified bitumen with both types of aggregate resulted in higher ER values. They also show that the bitumen modified with $3.91 \%$ RH-WMA showed the highest increase in the ER. The moisture damage resistance of a bitumen-aggregate with higher energy ratio is superior to the bitumenaggregate with lower value of energy ratio when other mixture properties are similar.

\subsection{CONCLUSION}

The effects of using RH-WMA on the engineering properties of bitumen was investigated in this study. Based on the laboratory works and analysis conducted in this study showed the addition of RH-WMA has a strong effect on penetration and ductility, where the penetration and ductility values increased with the addition of higher amounts of RH-WMA. Accordingly, the addition of RH-WMA decreased the softening point value of the bitumen. The results of the storage stability test show that the RH-WMA modified bitumen are stable. Moreover, RSM analysis shows close agreement between the estimated and the actual values, which suggest that the models could predict mixture properties adequately within the predetermined scope of factors.

In addition, the results for viscosity test show that the addition of RH-WMA lowered the viscosity of the modified bitumen. This shows that small values of viscosity improved the workability of RH-WMA modified bitumen. The thermal stability of RH-WMA modified bitumen, which was determined through the TGA test, show that RH-WMA has minimal effect on thermal stability. The DSC plot shows that there is a slight difference at the thermal degradation beginning temperature between the base bitumen and the RHWMA modified bitumen, which indicate that RH-WMA increased the thermal degradation of bitumen constituent efficiently.

Furthermore, analysis of the FTIR shows that there was no complex chemical reaction between the base bitumen and the RH-WMA modified bitumen. The results of the SFE test, which was obtained through the sessile drop (SD) device, show that adding RH-WMA to the base bitumen increased the total SFE component of the base binder. The increase in the total SFE suggests good adhesion between the bitumen and the aggregates. Additionally, RH-WMA modified bitumen reduced the extent of work of debonding of the bitumen over the aggregates by about $25 \%$, which is desirable when the concern is to reduce resistance to moisture-induced damage. The results for the energy ratio parameter show that the addition of RH-WMA increased the 
resistance of the mixtures to moisture-induced damage in virtually all cases.

\section{Acknowledgement}

The authors would like to express their gratitude to Universiti Kebangsaan Malaysia (UKM) for the financial support of this work (DIP-2017-004).

\section{References}

[1] Gandhi, T. 2008. Effects of Warm Asphalt Additives on Asphalt Binder and Mixture Properties. Clemson Univ. May: 161.

[2] Sampath, A. 2010. Comprehensive Evaluation of Four Warm Asphalt Mixture Regarding Viscosity, Tensile Strength, Moisture Sensitivity, Dynamic Modulus and Flow Number. Master of Science Thesis. University of Iowa, USA. 42 pages.

[3] Sheth, N. M. 2010. Evaluation of Selected Warm Mix Asphalt Additives. Master of Science Thesis, University of lowa, USA. 108 pages.

[4] Vaitkus, A., Čygas, D., Laurinavičius, A., and Perveneckas, Z. 2009. Analysis and Evaluation of Possibilities for the Use of Warm Mix Asphalt in Lithuania. Balt. J. Road Bridg. Eng. 4(2): 69-79.

[5] Button, J. W., Estakhri, C., and Wimsatt, A. 2007. A Synthesis of Warm Mix Asphalt. Texas Transp. Inst. 7(2): 94.

[6] Zaumanis, M. 2010. Warm Mix Asphalt Investigation. Master of Science thesis, Technical University of Denmark, Denmark. 111 pages.

[7] Capitão, S. D., Picado-Santos, L. G., and Martinho, F. 2012 Pavement Engineering Materials: Review on the Use of Warm-mix Asphalt. Constr. Build. Mater. 36: 1016-1024.

[8] Abdullah, M. E., Zamhari, K. A., Buhari, R., Khatijah, S., Bakar, A., Hidayah, N., Kamaruddin, M., Nayan, N., Hainin, M. R., Hassan, N. A., and Hassan, S. A. 2014. Warm Mix Asphalt Technology: A Review. Jurnal Teknologi. 3: 39-52.

[9] Angelo, J. D'., Harm, E., Bartoszek, J., Baumgardner, G. Corrigan, M., Cowsert, J., Harman, T., Jamshidi, M., Jones, W., Newcomb, D., Prowell, B., Sines, R., and Yeaton, B. 2008. Warm-Mix Asphalt: European Practice. US Department Transp. 68.

[10] Wang, H., Dang, Z., You, Z., and Cao, D. 2012. Effect of Warm Mixture Asphalt (WMA) Additives on High Failure Temperature Properties for Crumb Rubber Modified (CRM) Binders. Constr. Build. Mater. 35: 281-288.

[11] Hamzah, M. O., Kakar, M. R., and Hainin, M. R. 2015. An Overview of Moisture Damage in Asphalt Mixtures. J. Teknol. 73(4): 125-131.

[12] Kakar, M. R., M. Hamzah, O., Akhtar, M. N., and Woodward, D. 2016. Surface Free Energy and Moisture Susceptibility Evaluation of Asphalt Binders Modified with Surfactant-based Chemical Additive. J. Clean. Prod. 112: 2342-2353.

[13] Kakar, M. R., Hamzah, M. O., and Valentin, J. 2015. A Review on Moisture Damages of Hot and Warm Mix
Asphalt and Related Investigations. J. Clean. Prod. 99: 3958.

[14] Kim, D. H., Jeong, E., Oh, S. E., and Shin, H. S. 2010. Combined (alkaline+ultrasonic) Pretreatment Effect on Sewage Sludge Disintegration. Water Res. 44(10): 30933100.

[15] Hamzah, M. O., Golchin, B., and Tye, C. T. 2013. Determination of the Optimum Binder Content of Warm Mix Asphalt Incorporating Rediset Using Response Surface Method. Constr. Build. Mater. 47: 1328-1336.

[16] Jamshidi, A., Hamzah, M. O., and Zahed, M. A. 2013. Rheological Evaluation and Modeling of Sasobit $B$ Modified Asphalt Binder at High Temperatures Rheological Evaluation and Modeling of Sasobit $\AA^{\circledR}$-Modified Asphalt Binder at High Temperatures. Pet. Sci. Technol. 31 (November): 1574-1584.

[17] Zhang, F. and YU, J. 2010. The Research for HighPerformance SBR Compound Modified Asphalt. Constr. Build. Mater. 24(3): 410-418.

[18] Yao, H., You, Z., Li, L., Goh, S. W., Lee, C. H., Yap, Y. K., and Shi, X. 2013. Rheological Properties and Chemical Analysis of Nanoclay and Carbon Microfiber Modified Asphalt with Fourier Transform Infrared Spectroscopy. Constr. Build. Mater. 38: 327-337.

[19] Hamzah, M. O., Gungat, L., Yusoff, N. I. \& Valentin, J. 2016. Recycled Asphalt Pavement with Warm Mix Additive for Sustainable Road Construction. International Journal of Civil, Environmental, Structural, Construction and Architectural Engineering. 10: 328-331.

[20] Niu, Y., Zhu, Z., Xiao, J., Liu, Z., and Liang, B. 2016. Evaluation of Storage Stability of Styrene-butadienestyrene Block Copolymer-modified Asphalt via Electrochemical Analysis. Constr. Build. Mater. 107: 38-43.

[21] Liang, M., Xin, X., Fan, W., Luo, H., Wang, X., and Xing, B. 2015. Investigation of the Rheological Properties and Storage Stability of CR/SBS Modified Asphalt. Constr. Build. Mater. 74: 235-240.

[22] Al-Mansob, R. A., Ismail, A., Alduri, A. N., Azhari, C. H., Karim, M. R., and Yusoff, N. I. M. 2014. Physical and rheological properties of epoxidized natural rubber modified bitumens. Constr. Build. Mater. 63: 242-248.

[23] Zainoodin, A. M., Kamarudin, S. K., Masdar, M. S., Daud, W. R. W., Mohamad, A. B., and Sahari, J. 2015. Optimization of a Porous Carbon Nanofiber Layer for the Membrane Electrode Assembly in DMFC. Energy Convers. Manag. 101: 525-531.

[24] Gungat, L., Hamzah, M. O., and Yusoff, N. I. 2015. Rheological and Environmental Evaluation of Reclaimed Asphalt Incorporating a Wax Additive. 113-119.

[25] Gungat, L., Yusoff, N. I. M., and Hamzah, M. O. 2016. Effects of RH-WMA Additive on Rheological Properties of High Amount Reclaimed Asphalt Binders. Constr. Build. Mater. 114: 665-672.

[26] Wasiuddin, N. M. 2007. Effect of Additives on Surface Free Energy Characteristics of Aggregates and Binders in Hot Mix Asphalt. PhD (Doctor of Phylosophy) Thesis. University of Oklahoma, USA. 166 pages.

[27] Koc, M. 2013. Development of Testing Protocols for Direct Measurement of Contact Angles on Aggregate and Asphalt Binder Surface Using a Sessile Drop Device. Master of Science thesis, Oklahoma State University, USA. 79 pages. 